\title{
The Effect of Shell as a Substitution of Coard Aggregate with Superplasticizer Additional on the Compression Strength of Concrete
}

\author{
Lina Flaviana Tilik ${ }^{1, *}$ Bambang Hidayat Fuady ${ }^{1}$ Suhadi Suhadi ${ }^{1}$ Rosy Armaini ${ }^{1}$ \\ Fadhila Firdausa ${ }^{1}$ Muhammad Rifqi Agusri ${ }^{1}$ Puji Hartoyo ${ }^{1}$
}

\author{
${ }^{1}$ Sriwijaya State Polytechnic \\ ${ }^{*}$ Corresponding author. Email: lina_tilik@yahoo.co.id
}

\begin{abstract}
Concrete is a type of building structure material, both buildings, bridges, and roads. Concrete is a construction material obtained from mixing sand, gravel, or crushed stone, cement, and water. To improve the properties of concrete, several kinds of additives that have certain functions are added to the concrete mixture, to improve or improve the properties of concrete, namely increasing the workability, durability, and hardening time of the concrete. Shells with excellent quality and shape are used as craft materials, while bad shapes can cause waste which results in a series of other problems, especially the cleanliness of the surrounding environment. This study aims to determine the effect of shells as a substitution of coarse aggregate with superplasticizer added material on the compressive strength of concrete. The specimens used were cylindrical with a diameter of $15 \mathrm{~cm}$ and a height of $30 \mathrm{~cm}$. The composition of the shells determined in this study was $0 \%, 5 \%, 10 \%, 15 \%, 20 \%$ and $0.5 \%$ superplasticizer added. The planned concrete quality is $\mathrm{Fc}=25 \mathrm{MPa}$. The value of the compressive strength of concrete increased with the addition of shells by $5 \%$ and decreased in the addition of shells above $5 \%$ with $0.5 \%$ superplasticizer added. The compressive strength of normal concrete and $0.5 \%$ superplasticizer concrete is $28.26 \mathrm{MPa}$ and $29.15 \mathrm{MPa}$ at the age of 28 days and the compressive strength of shell concrete with a composition of 5\%,10\%,15\%, and $20 \%$ added with superplasticizer $0,5 \%$ produces a compressive strength of $30.78 \mathrm{MPa} ; 26.78 \mathrm{MPa} ; 24.71 \mathrm{MPa}$, and $22.93 \mathrm{MPa}$ at the age of 28 days.
\end{abstract}

Keywords: compressive strength, Blood clam shell, Superplasticizer

\section{INTRODUCTION}

\subsection{Background}

The need for housing for the people of Indonesia is increasing. This is accompanied by an increase in the number of people in the country. To meet the needs of cheap and decent housing for the people in the country, innovative steps are needed by utilizing existing waste.

Environmentally friendly concrete is concrete composed of environmentally friendly materials. An example of environmental damage due to the use of natural resources is the destruction of rock hills. The increasing need for concrete materials triggers the mining of stone, one of the constituent materials of concrete as coarse aggregate, on a large scale which causes a decrease in the number of natural resources available for concrete purposes. Coarse aggregate is the most dominant constituent of concrete. The shells are made of lime so that it can be used as a coarse aggregate for concrete.

In this study, shell waste was used as a substitute for coarse aggregate. Indonesia is an archipelagic country, with millions of potentials. With an area of 5.8 million $\mathrm{km}$ of water and a coastline of $81,000 \mathrm{~km}$, Indonesia has enormous potential in terms of managing marine resources, one of which is shellfish.

So far, most people, especially the Kenjeran area, only use mussel meat, while clam shells have not been used optimally. This causes problems in the form of shellfish waste that accumulates in coastal areas. Considering the composition of mussel shells is more than the meat, which is about $70 \%$ shell and $30 \%$ meat. 
So far, some of the shells of excellent quality and shape are used for craft materials, while those that are not utilized have caused a series of other problems, especially environmental hygiene, thus disturbing the health of the surrounding community. One of the ways to use shells is to substitute them for making concrete. Shellfish is a waste that can be used as a substitute for coarse aggregate.

Research on the use of clam shells is still being developed to get a better composition of ingredients. The percentage of clam shells as well as the addition of appropriate superplasticizer additives are still being conducted. The use of different superplasticizers will affect the result. In this study, the superplasticizer used was $0.5 \%$ polycarboxylate superplasticizer for all concrete mixtures.

In the literarture review according to I.G.A. Neny Purnawirati and Fransiska Moi (2021) [3] in the results of the study using flying ash added materials and superplasticizers amounting to $0.4 \%$ of cement weight obtained strong concrete press results of $14.34 \mathrm{MPa}$ at the age of 28 days and $18.12 \mathrm{MPa}$ at the age of 56 days. Meanwhile, based on the results of the research of Restu Andika and Hendramawat Aski Safarizki (2019) [5] regarding the utilization of shell shells on strong concrete presses obtained an increase of $7 \mathrm{MPa}$ in a mixture of $5 \%$ and $3 \mathrm{MPa}$ in a mixture of $7.5 \%$.

According to Andi Afdilla Amiruddin, et al. (2017) [2] regarding the utilization of kerrang shell waste and ceramic waste as a substitute for fine aggregates and coarse aggregates obtained strong decreases in concrete press by $10.94 \%, 3.80 \%, 23.60 \%$ and $25.88 \%$ against normal concrete mixtures. Related research was also conducted by Sudirman Latjemma, et al. (2020) [8] on the use of kerrang skin as a coarse aggregate obtained a mixed result of $5 \% 25.92 \mathrm{MPa}$, a mixture of $10 \% 24.28$ $\mathrm{MPa}$ and $32.11 \mathrm{MPa}$, and a mixture of $15 \% 23.02 \mathrm{MPa}$ and $34.92 \mathrm{MPa}$.

In addition, Rinaldhi Ridha and Hieryco MManalip (2020) [6] also conducted research on the effect of the use of rice conch caangkang powder as cement subtitusi obtained partial subsitution results can only be done with a maximum addition of $5 \%$.

Based on the above background, the problems that will be discussed in this research are:

1. What are the characteristics of the compressive strength of concrete with shellfish proportions of $0 \%, 5 \%, 10 \%, 15 \%$, and $20 \%$ as a substitute for coarse aggregate and superplasticizer added with a concentration of $0.5 \%$ in the concrete mixture?

2. What is the percentage of addition of shells as a substitute for coarse aggregate in the concrete mixture to produce optimal concrete compressive strength?

3. What is the effect of adding superplasticizer to shell concrete?

\subsection{Concrete}

Concrete is a set of mechanical and chemical interactions of the constituent materials and meets the limit strength required by the planner and meets serviceability which can also be interpreted as reliable service by meeting economic criteria. [4]. The definition of concrete is a mixture of Portland cement or other hydraulic cement, fine aggregate, coarse aggregate, water, with or without additives that form a solid mass.

\subsection{Blood Clam Shell}

Blood clams belong to the family Arcidae and the genus Anadara. Blood clams belong to the class Lamellibranchiata along with oysters, mussels, and the like. The following is the chemical composition of blood clam shells:

Table 1. Chemical Composition of Blood Shells

\begin{tabular}{|c|c|}
\hline chemical components & Composition (\%) \\
\hline $\mathrm{CaO}$ & 66,70 \\
\hline $\mathrm{SiO}_{2}$ & 7,88 \\
\hline $\mathrm{Fe}_{2} \mathrm{O}_{3}$ & 0,03 \\
\hline $\mathrm{MgO}$ & 22,28 \\
\hline $\mathrm{Al}_{2} \mathrm{O}_{3}$ & 1,25 \\
\hline
\end{tabular}

(Source: Addriyanus, 2015) [1]

\subsection{Additives}

Admixtures are materials that are added to a concrete mixture other than cement, aggregates, and water. This added material is given immediately before or when the process of mixing the concrete mixture begins. In general, the function of added materials is to produce concrete that is better in terms of workmanship, quality, and economy. [7].

A slump of concrete is an indicator of the dilution of concrete. In terms of implementation, the slump figure shows the ease of workability (workability). The thinner the concrete, the easier it is to work, but the thickness of the concrete mixture has certain limitations, according to the type of construction. Too thick concrete will easily become brittle and break easily, too watery-even concrete will flow easily and have low strength.

\subsection{Compressive Strength of Concrete}

The main strength of concrete is its compressive strength. The value of the compressive strength of concrete increases with increasing age and at the age of 
28 days, the concrete reaches its maximum strength. 28 days old. The loading on the compressive strength test is in the form of a load that works continuously distributed through the center of gravity. The formula for calculating the compressive strength of concrete, namely:

$$
f^{\prime} c=\frac{P}{A}
$$

Information:

$f^{\prime} \mathrm{c}=$ compressive strength of concrete $\left(\mathrm{kg} / \mathrm{cm}^{2}\right)$

$\mathrm{P}=\operatorname{load}(\mathrm{kg})$

$\mathrm{A}=$ cross-sectional area $\left(\mathrm{cm}^{2}\right)$

\section{RESEARCH METHODS}

\subsection{Tools and materials}

The manufacture and testing of the compressive strength of the specimens were conducted at the Materials Testing Laboratory of the Civil Engineering Department of the Sriwijaya State Polytechnic, Palembang. Concrete making materials are as follows: coarse aggregate, fine aggregate, Portland cement, shells, and additives (Superplasticizer).

Meanwhile, the equipment used included: equipment for the source of aggregate (a set of $0.075 \mathrm{~mm}$ to $38 \mathrm{~mm}$ sieves, a density spoon, scales, brushes, a set of truncated cones, cylindrical vessels, pounding rods, and Rudolf's vessels); equipment for sourcing cement (a set of mixers, a spatula, a set of Vicat tools, and a le chatelier tube); equipment for casting sources (stir box, stirrer, cylindrical vessel, spec box, density spoon, a set of Abrams cones).

\subsection{Test Object}

Concrete is a set of mechanical and chemical interactions of the constituent materials and meets the limit strength required by the planner and meets serviceability which can also be interpreted as reliable service by meeting economic criteria. [4]. The definition of concrete is a mixture of Portland cement or other hydraulic cement, fine aggregate, coarse aggregate, water, with or without additives that form a solid mass.

The sample used is a cylinder with a diameter of 15 $\mathrm{cm}$ and a height of $30 \mathrm{~cm}$. Samples were tested at the age of 7,14 , and 28 days. The number of samples is 54 samples as shown in the following table:
Table 2. Research Sample

\begin{tabular}{|c|c|c|c|c|c|}
\hline \multirow{2}{*}{ No. } & \multirow[t]{2}{*}{ Test object code } & \multirow{2}{*}{$\begin{array}{c}\text { Blood } \\
\text { Clam Shell } \\
(\%)\end{array}$} & \multicolumn{3}{|c|}{$\begin{array}{c}\text { Testing Age } \\
\text { (Days) }\end{array}$} \\
\hline & & & 7 & 14 & 28 \\
\hline 1 & $\mathrm{BN}$ & - & 3 & 3 & 3 \\
\hline 2 & BSP & - & 3 & 3 & 3 \\
\hline 5 & BK5\% SP 0,5\% & 5 & 3 & 3 & 3 \\
\hline 4 & BK10\% SP 0,5\% & 10 & 3 & 3 & 3 \\
\hline 5 & BK15\% SP 0,5\% & 15 & 3 & 3 & 3 \\
\hline 6 & BK20\% SP 0,5\% & 20 & 3 & 3 & 3 \\
\hline \multicolumn{3}{|c|}{ TOTAL } & \multicolumn{3}{|c|}{54} \\
\hline
\end{tabular}

$\begin{array}{ll}\text { Information: } & \text { : Normal Concrete } \\ \text { BN } & \text { : Concrete Superplastizer } \\ \text { BSP } & : \text { 5\% Shell Concrete } \\ \text { BK5\% SP0.5\% } & \text { superplasticizer 0.5\% } \\ \text { BK10\% SP0.5\% } & : \text { 10\% Shell Concrete } \\ \text { superplasticizer 0.5\% } \\ \text { BK15\% SP0.5\% } & \text { : Concrete Shells 15\% } \\ \text { superplasticizer 0.5\% } & \text { : 20\% Shell Concrete } \\ \text { BK20\% SP0.5\% } & \text { superplasticizer } 0.5 \%\end{array}$

\section{RESULTS AND DISCUSSION}

\subsection{Calculation of Concrete Mix (Mix Design)}

This concrete mix design uses the SNI 03-2834-2000 standard. The provisions used for this concrete mixture are as follows: (i) concrete with a compressive strength of FC 25MPa for 28 days; (ii) Batu Raja Type 1 Portland cement is used; (iii) the design slump height is taken from $60-180 \mathrm{~mm}$; (iv) the maximum coarse aggregate grain size is $40 \mathrm{~mm}$; (v) fine aggregate used zone 2; (vi) maximum water-cement factor of 0.52 ; (vii) the number of shells is taken from the percentage of coarse aggregate.

\subsection{Concrete Compressive Strength Test Results}

Table 3. Mixed Proportion

\begin{tabular}{|c|c|c|c|c|}
\hline NO. & $\begin{array}{c}\text { Cement } \\
\left(\mathrm{kg} / \mathrm{m}^{3}\right)\end{array}$ & $\begin{array}{c}\text { Water } \\
\left(\mathrm{Kg} / \mathrm{m}^{3}\right)\end{array}$ & $\begin{array}{c}\text { coarse } \\
\text { aggregate } \\
\left(\mathrm{Kg} / \mathrm{m}^{3}\right)\end{array}$ & $\begin{array}{c}\text { fine } \\
\text { aggregate } \\
\left(\mathrm{Kg} / \mathrm{m}^{3}\right)\end{array}$ \\
\hline 1 & 394,23 & 135,903 & 657,676 & 1087,201 \\
\hline
\end{tabular}


Table 4. Compressive Strength of Concrete

\begin{tabular}{|c|l|c|c|c|}
\hline \multirow{2}{*}{ No. } & \multirow{2}{*}{ Test object code } & \multicolumn{3}{|c|}{$\begin{array}{c}\text { Average Compressive } \\
\text { Strength of Test Objects at } \\
\text { Age (MPa) }\end{array}$} \\
\cline { 3 - 5 } & & 7 & 14 & 28 \\
\hline 1 & BN & 18,37 & 24,87 & 28,26 \\
\hline 2 & BSP & 18,95 & 25,65 & 29,15 \\
\hline 5 & BK5\% SP 0,5\% & 20,00 & 27,08 & 30,78 \\
\hline 4 & BK10\% SP 0,5\% & 17,41 & 23,57 & 26,78 \\
\hline 5 & BK15\% SP 0,5\% & 16,06 & 21,74 & 24,71 \\
\hline 6 & BK20\% SP 0,5\% & 14,91 & 20,18 & 22,93 \\
\hline & & & & \\
\hline
\end{tabular}

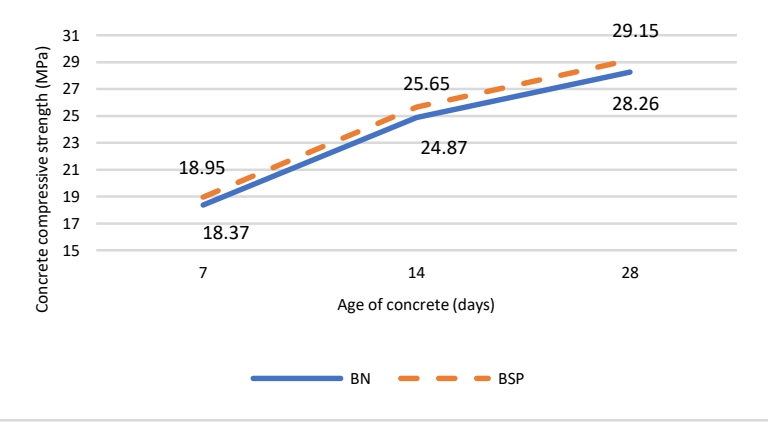

Figure 1 Graph of Compressive Strength Test for Normal Concrete and Superplasticizer Concrete

From Figure 1, the average compressive strength of normal concrete at the age of 7,14 , and 28 days is 18,37 $\mathrm{MPa} ; 24,87 \mathrm{MPa}$; and 28,26 MPa. while the compressive strength of concrete with $0.5 \%$ superplasticizers added at the age of 7,14, and 28 days was 18,95 $\mathrm{MPa} ; 25,65 \mathrm{MPa}$; and 29,15 MPa. From the results of testing the compressive strength of concrete with $0.5 \%$ superplasticizer added material, it increased at the age of 28 days by $29,15 \mathrm{MPa}$ compared to normal concrete compressive strength of 28,26 MPa.

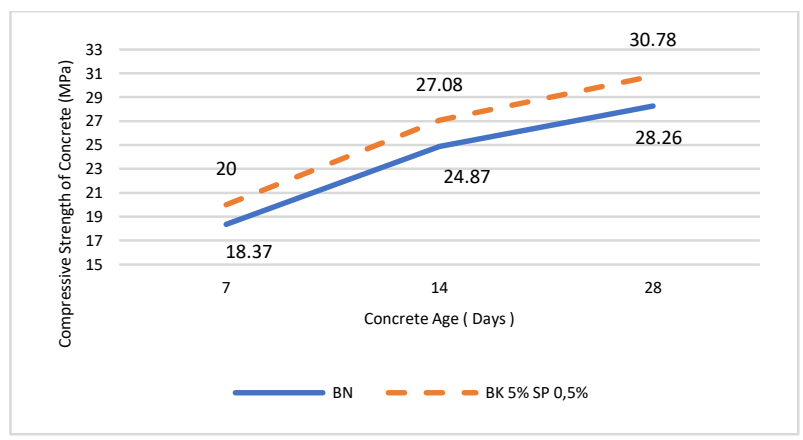

Figure 2 Graph of Compressive Strength Test of Normal Concrete and Shells 5\% Superplasticizer 0.5\%
From Figure 2, the average compressive strength of normal concrete at the age of 7,14 , and 28 days is 18,37 $\mathrm{MPa} ; 24,87 \mathrm{MPa}$; and 28,26 MPa. while the compressive strength of concrete with added 5\% shellfish superplasticizers $0,5 \%$ at the age of 7,14 , and 28 days is 20,00 MPa; 27,08 MPa; and 30,78 MPa. From the results of testing the compressive strength of concrete with added material of $5 \%$ shellfish superplasticizers $0,5 \%$ increased at 28 days of age by $30,78 \mathrm{MPa}$ compared to normal concrete compressive strength of $28,26 \mathrm{MPa}$.

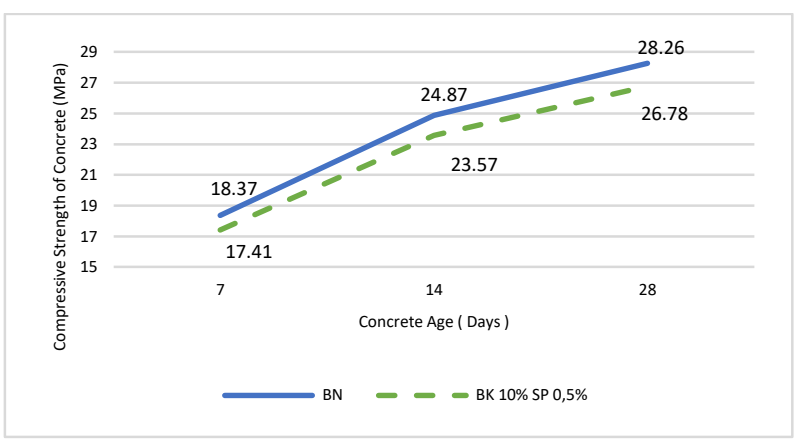

Figure 3 Graph of Compressive Strength Test of Normal Concrete and Shells 10\% Superplasticizer $0.5 \%$

From Figure 3, the average compressive strength of normal concrete at the age of 7,14 , and 28 days is 18.37 $\mathrm{MPa}$; $24.87 \mathrm{MPa}$; and 28.26 MPa. while the compressive strength of concrete with $10 \%$ superplasticizers $0.5 \%$ shells added at the age of 7, 14, and 28 days was 17.41MPa; 23.57 MPa; and 26.78 MPa. From the results of testing the compressive strength of concrete with added material of shellfish $10 \%$ superplasticizer $0.5 \%$ decreased at 28 days of age by $26.78 \mathrm{MPa}$ compared to normal concrete compressive strength of $28.26 \mathrm{MPa}$.

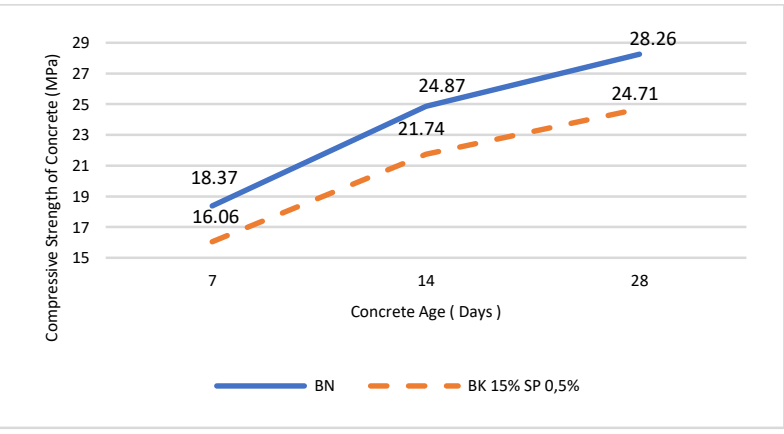

Figure 4 Graph of Compressive Strength Test of Normal Concrete and Shells $15 \%$ Superplasticizer $0.5 \%$

Figure 4 shows that the average compressive strength of normal concrete at the age of 7,14 , and 28 days is $18,37 \mathrm{MPa}$; 24,87 $\mathrm{MPa}$; and 28,26 $\mathrm{MPa}$. while the compressive strength of concrete with $15 \%$ superplasticizer $0.5 \%$ shells added at the age of 7,14 , and 28 days was $16,06 \mathrm{MPa} ; 21,74 \mathrm{MPa}$; and 24,71 $\mathrm{MPa}$. 
From the results of testing the compressive strength of concrete with added material of $15 \%$ superplasticizer $0.5 \%$ shells, decreased at 28 days of age by $24,71 \mathrm{MPa}$ compared to normal concrete compressive strength of $28,26 \mathrm{MPa}$.

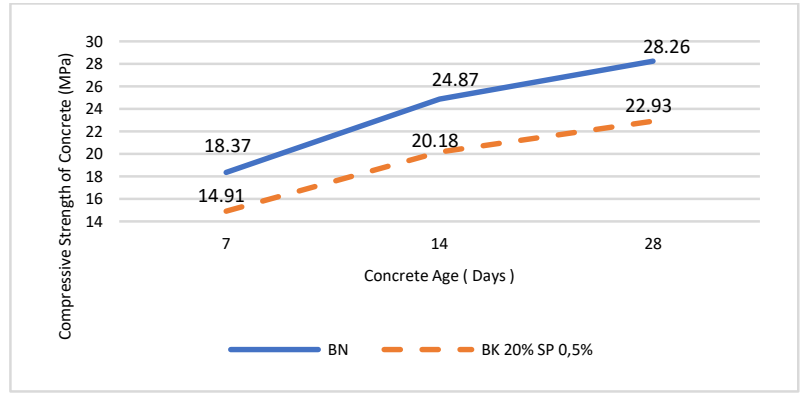

Figure 5 Graph of Compressive Strength Test of Normal Concrete and Shells 20\% Superplasticizer $0.5 \%$

Figure 5 shows that the average compressive strength of normal concrete at the age of 7,14 , and 28 days is 18,37 $\mathrm{MPa} ; 24,87 \mathrm{MPa}$; and 28,26 $\mathrm{MPa}$. while the compressive strength of concrete with $20 \%$ superplasticizers added shells of $0.5 \%$ at the age of 7,14 , and 28 days was 14,91 MPa; 20,18 MPa; and 22,93 MPa. From the results of testing the compressive strength of concrete with added ingredients of $20 \%$ superplasticizers $0.5 \%$ shells decreased at 28 days of age by $22,93 \mathrm{MPa}$ compared to normal concrete compressive strength of 28,26 MPa.

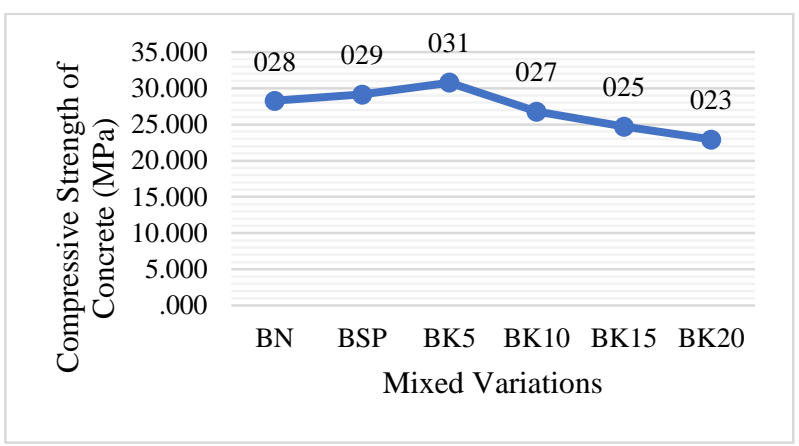

Figure 6 Comparative Graph of the Effect of Addition of Shellfish Shells and $0.5 \%$ Superplasticizer

From Figure 6. at the age of 28 days, the normal compressive strength of concrete without a mixture of shells and superplasticizer is $28.26 \mathrm{MPa}$, the compressive strength of concrete with the addition of $0.5 \%$ superplasticizer is $29.15 \mathrm{MPa}$, and the compressive strength of concrete with the addition of shells $5 \% ; 10 \%$; 15 ; and $20 \%$ with $0.5 \%$ superplasticizer which is $30.78 \mathrm{MPa}$; 26.78MPa; 24.71MPa; and 22.93MPa. That the compressive strength of concrete has increased after the addition of a superplasticizer and experienced a considerable increase after adding 5\% shells, but after adding shells exceeding 5\% composition, the compressive strength of concrete experienced a considerable decrease, so that the composition of the addition of shells was good. for concrete mixtures not to exceed $5 \%$.

\section{CONCLUSION}

Based on the test results, the compressive strength of normal concrete and $0.5 \%$ superplasticizer concrete is $28.26 \mathrm{MPa}$ and $29.15 \mathrm{MPa}$, while the compressive strength of shell concrete with a composition of $5 \%, 10 \%$, $15 \%$, and $20 \%$ added with superplasticizer $0,5 \%$ yielded compressive strength of $30.78 \mathrm{MPa}, 26.78 \mathrm{MPa}, 24.71$ $\mathrm{MPa}$, and $22.93 \mathrm{MPa}$. The compressive strength of concrete increased after being added with $0.5 \%$ superplasticizer added and for the addition of shells it increased at a percentage of 5\% while the compressive strength of concrete with the addition of shells above $5 \%$ decreased, so that the characteristics of a good concrete mixture to use were shell concrete. shellfish with a composition of $5 \%$ with added material as superplasticizer as much as $0.5 \%$.

\section{ACKNOWLEDGMENTS}

The author would like to thank those who have provided financial support for the implementation of this activity, namely Sriwijaya State Polytechnic and Pt. Pilar Mas Perkasa who has given the opportunity to conduct this research.

\section{REFERENCES}

[1] Addriyanus Tarntra, 2015, Pengaruh Komposisi dan Ukuran Makro Serbuk Kulit Kerang Darah (Anadora Granosa) Terhadap Komposit Epoksi-PS/ Serbuk Kulit Kerang Darah (SKKD) Medan: Tesis Fakultas Teknik, Departemen Teknik Kimia USU.

[2] Andi Afdilla Ammiruddin, Salma Alwi, dan Daru Purbaningtyas, 2017, Pengaruh Pemanfaatan Limbah Cangkang Kerang Dan Limbah Keramik Sebagai Substitusi Agregat Halus Dan Agregat Kasar pada Beton Terhadap Kuat Tekan Beton, Politeknik Negeri Samarinda.

[3] I.G.A. Neny Purnawirati dan Fransiska Moi, 2021, Penggunaaan Variasi Abu Terbang dan Superplasticizer Dalam Pembuatan Beton Ringan Struktur, Politeknik Negeri Bali.

[4] Mulyono, Tri, 2005, Teknologi Beton, Edisi kedua, Yogyakarta: Andi Yogyakarta.

[5] Restu Andika, dan Hendramawat Aski Safarizki, 2019, Pemanfaatan Limbah 
Cangkang Kerang Dara (Ananda Granosa) Sebagai Bahan Tambah Dan Komplemen

[6] Terhadap Kuat Tekan Beton Normal, Jurnal Universitas Veteran Bangun Nusantara 1, 1.

[7] Rinaldhi Ridha'al Syariffudin Hieryco Manalip, dan Mielke R. I. A. J. Mandoringin, 2020, Pengaruh Penggunaan Serbuk Cangkang Keong Sawah Sebagai Substitusi Parsial Seman Terhadap Nilai Modulus Elastisitas, Universitas Sam Ratulangi Manado.
[8] Setiawan, Agus, 2016, Perencanaan Struktur Beton Bertulang, Jakarta: Penerbit Erlangga

[9] Sudirman Letjemma, Suratnan Tahir, dan Haris, 2020, Studi Pemanfaatan Limbah Kulit Kerang Sebagai Agregat Kasar Pada Beton Normal, Jurnal Universitas Manado Tolitoli 4, 1, 29-38 